\title{
技術資料
}

\section{炭化珪素の CVD・コーティング装置}

\author{
平井敏雄* 浅倉寛行 ${ }^{* *}$ 佐々木 真***
}

1. はじめに

$\mathrm{SiC}$ は古くから研磨材や耐火材として知られているが, 近年, ファイン化技術の進歩に伴って微構造制御 $\rightarrow$ 性質制御が可能になり, その結果, $\mathrm{SiC}$ は優れた高温強 度: 耐酸化性, 耐熱衝撃性を持つ材料となった。かくし て $\mathrm{SiC}$ は過酷な条件下で使用される高温ガスタービン 用材料を主とした高温構造材料として注目され, 省エネ ルギー・省資源時代において $\mathrm{Si}_{3} \mathrm{~N}_{4}$ と共にファインセラ ミックスを代表する材料となった (1)-(4).

しかしながら， $\mathrm{SiC}$ は共有結合性の強い化合物である ので, 焼結が困難であり, 従って通常の焼結法では緻密 な成形体は得られ難い。そこで, 高性能 $\mathrm{SiC}$ を製造す るために, 反応焼結 $(\mathrm{RS})$ 法, 再結晶 $(\mathrm{RC})$ 法, 常圧焼 結(NS)法, ホットプレス(HP)法, 化学気相析出(CVD) 法, などの成形技術の開発研究が世界各国で行われてい $ろ^{(5)}$.

CVD 法以外の方法は何れも粉末を原料とし, 通常, 焼結助剂を添加した焼結プロセスを経てバルク材が作ら れるために, 高純度・高密度のものは得られ難い。

一方, CVD法では, 原料にガスを用いて気体から固 体を直接合成するので, 焼結助剂を添加することなく理 論密度を有する緻密な成形体が得られる.さらに CVD 法ではバルク材はもとより薄膜を合成することも可能で ある(1).

CVD-SiC は, 切削工具や粒状核燃料へのコーティ ング(6), 炭素材の酸化防止コーティング(7), 宇宙関係の 耐熱コーティング(7), プレスガラス用の型表面のコーティ

* 東北大学教授; 金属材料研究所

** 品川白棟瓦株式会社技術研究所主任研究員

*** 東北大学助手; 金属材料研究所

Apparatus for Chemical Vapor Deposition of Silicon Carbide; Toshio Hirai*, Hiroyuki Asakura**, Makoto Sasaki*** $(*, * * *$ Institute for Materials Research, Tohoku Univ., Sendai, ** Research Center, Shinagawa Refractories Co., Ltd., Bizen) Keywords : silicon carbide, chemical vapor deposition, apparatus, chamber, coating, in-situ composite 1987 年 3 月 26 日受理
ング(9) のような表面改質被膜として, およびガスタービ

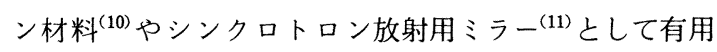
な材料となってきた。エレクトロニクス関係では, 青色 発光素子として注目されている(12).

しかしながら，CVD技術は未だに「know-how の固まり」と言われているように，CVD装置や CVD 条件によって, 得られる CVD-SiCの性質は著しく異 なる、性質に大きな影響を及ぼすCVD因子としては，

（1）基材の配置，(2)原料ガスの混合方法，(3)ガスの流 れ, (4)ガスの線速度, (5)析出温度, (6)ガスの予熱, (7)ガスの圧力, などがある.乙れらの CVD因子は CVD 反応炉の形状之密接な関係があるが，乙の方面の 基礎的な研究は不十分であり, 反応炉の設計や析出条件 の設定は経験に頼っているのが現状である.

近年, CVD-SiC の開発研究が多くの企業で始めら れているが，CVD装置の設計は手探りの状態で行われ ている，そこで，本稿では，反応炉の形状に重点を置い て, 現在までに報告されているいくつかをまとめて参考 に供する。

CVD法によれば, 析出物は, 粉末, ホイスカー, 針 状単結晶, 薄膜, 板, などの状態で得られるが, こてで は薄膜および板状の $\mathrm{SiC}$ に関係するものについてのみ 取り扱う。

\section{CVD-SiC の構造と性質}

CVD-SiCの表面組織には, 各粒の結晶面が現れて いる facet structure と半球状の凹凸からなる pebble structureの 2 種類がある. 前者は結晶性が良く，低圧 条件で得られる(13). 半導体用基板としては前者が良い が, 合成速度は遅い。

CVD-SiC と焼結 $\mathrm{SiC}$ 成形体の最む顕著な違いは粒 界に見られる。CVD-SiCでは粒界三重点にも異物は 全く存在しない(14).

結晶型は通常の条件で得られたものは $\beta$ 型で,一般 に(111) 抢よび (220)配向をもつ(13). 密度は約 $3.2 \times 10^{3}$ $\mathrm{kg} / \mathrm{m}^{3}$ で理論密度と一致する. 
表 1 CVD- $\mathrm{SiC}$ の諸性質.

\begin{tabular}{|c|c|c|c|}
\hline 物 & カタログ値* & 文献值 & 文 \\
\hline 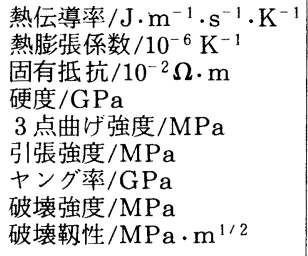 & $\begin{array}{l}67-71 \\
4.4-4.9 \\
1-14 \\
27-34(\mathrm{HK}) \\
200-690 \\
590 \\
320 \quad- \\
\quad-\end{array}$ & $\begin{array}{l}58-70 \\
4.9^{* *} \\
- \\
31(\mathrm{HV}) \\
800 \\
- \\
275-465 \\
650 \\
3.8\end{array}$ & $\begin{array}{l}(15) \\
(11) \\
(16) \\
(16) \\
(10),(17) \\
(16) \\
(16)\end{array}$ \\
\hline
\end{tabular}

*東洋力ーボン侏, 三井造船㑣, 東芝セラミックス侏, 日本 カーボン瑚

** 293-1273 K の平均值

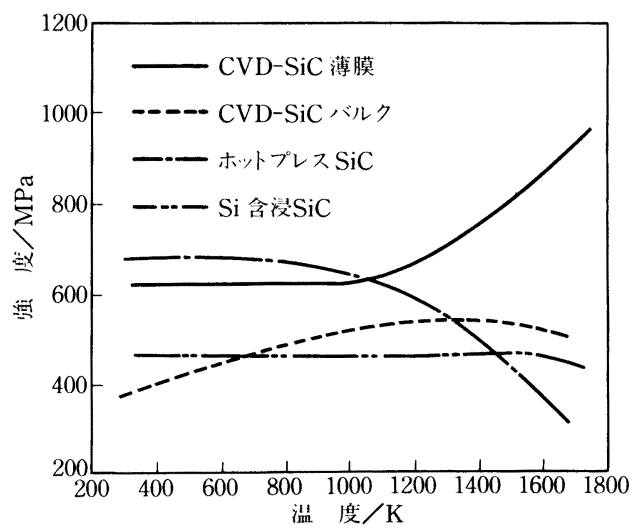

図 $1 \mathrm{SiC}$ の合成法による曲げ強度の比較 ${ }^{(10(\mathbf{a})),(17) .}$

CVD-SiC の性質の一例を表 1 亿示す.

硬度は配向の影響を著しく受け，(220)配向のものよ りも(111)配向の方が硬度は高い，乙れはスリップ系と 関係がある ${ }^{(16)}$.

3 点曲げ法で測定した強度を図 1 亿示す.CVD-SiC 薄膜の曲げ強度の最高值は約 $1300 \mathrm{MPa}$ で, $1000 \mathrm{~K}$ 以上 の高温になっても強度の低下はない(18). CVD-SiC 薄 膜とバルクとの曲げ強度の違いは, 膜中の内部応力が原 因していると考えられている.

\section{3. $\mathrm{SiC}$ の CVD}

\section{（1）基材}

$\mathrm{CVD}$ 法で $\mathrm{SiC}$ 膜あるいは板を合成する場合には必ず 基材が用いられる。基材の選択際しては次のような考 慮が必要である.

・1273〜1773 K の合成温度に耐えるとと.

・主として塩素系の反応ガス抢よび生成ガスと反応し ないてと。

$\cdot \mathrm{SiC}$ と熱膨張係数が近いとと.
・生成した $\mathrm{SiC}$ と反応しないこと.

これらのことから，基材に用いられる金属としては Mo, Wなどに限られている(19). 多くの場合, 基材には セラミックスが用いられる.

最も重要なパラメーターは熱膨張係数である.

$\mathrm{SiC}$ は一般に高温で安定な黒鉛を基材として合成され ることが多い，黒鉛には異方性を有するものと等方性の あのがある。1273 K に扔いて，異方性黒鉛では，X方 向の熱膨張は約 $0.25 \%$ であるのに対して, Y 方向のそ れは $0.55 \%$ である。一方，等方性黒鉛では方向による 熱膨張の差は殆ど無く, 約 $0.55 \%$ である ${ }^{(7(b))}$. また, 最近製造されている等方性黒鉛の熱膨張係数の力夕ログ 值は $(4.0 \sim 4.6) \times 10^{-6} \mathrm{~K}^{-1}$ である。

CVD-SiC の熱膨張係数は表 1 亿示したように，(4.4 〜 4.9) $\times 10^{-6} \mathrm{~K}^{-1}$ で, 等方性黒鉛のそれに極めて近い. 半導体用サセプターとして CVD-SiC をコーティング する黒鉛に等方性黒鉛が使われているのはての理由によ る. $\mathrm{SiC}$ は圧縮には強く, 引っ張りには弱いので, $\mathrm{SiC}$ 膜としては圧縮力が作用する状態であることが望ましい， 従って, 基材としては熱膨張係数が $\mathrm{SiC}$ より小さい屯 のは好ましくない，Lloyd 等 ${ }^{(20)}$ は, 異方性の強い基材 を使うと合成後の冷却中に被覆層に肉眼で判別できるよ うなクラックが発生すると述べている.

最近, 焼結セラミックスの表面改質に CVD-SiCを コーティングする試みがなされている.

焼結セラミックスの熱膨張係数 $\left(10^{-6} \mathrm{~K}^{-1}\right)$ は, $\mathrm{SiC}$ : 4.3 5.8, TiC: 7.7 9.5, $\mathrm{Si}_{3} \mathrm{~N}_{4}: 2.5 \sim 3.7, \mathrm{Al}_{2} \mathrm{O}_{3}: 8.0$ 〜9.3である. これらの值から，焼結 $\mathrm{SiC}$ の上には CVD$\mathrm{SiC}$ コーティングが可能であることが分かる．反応焼結 $\mathrm{Si}_{3} \mathrm{~N}_{4}$ 上にコーティングされた $\mathrm{SiC}$ には多くのクラック が観察されている. また，常圧焼結 $\mathrm{Si}_{3} \mathrm{~N}_{4}$ の場合には， $100 \mu \mathrm{m}$ の厚さの $\mathrm{SiC}$ をコーティングすると基材から剥 離してしまう(21)。

基材として上述した黒鉛や焼結セラミックス以外にも，

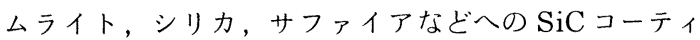
ングも試みられている(22). $\mathrm{Al}_{2} \mathrm{O}_{3}$ 基材を用いた場合,

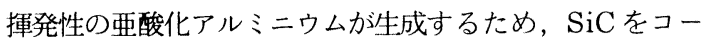
ティングすることはできなかった。

\section{（2）原料および合成条件}

CVD-SiC の合成には，1 分子内に $\mathrm{Si}$ と C の両元素 を含む原料が広く用いられているが，合成条件によって は $\mathrm{Si}$ 源と C 源が別々の物質から供給されることも多い. 表 2 によく使用されている原料を示す.メチルトリクロ ロシラン(以下 MTS と略記する) は 1 分子中に $\mathrm{Si}$ と C をそれぞれ 1 原子ずつ持っているのでよく用いられてい る原料である。しかしながら，MTSを使っても必ずし あ $\mathrm{SiC}$ が単相で得られるわけではない。図 2 にTS 
表 2 CVD-SiC 合成用原料ガス ${ }^{(22)}$.

\begin{tabular}{l|l:l:l}
\hline \hline SiよCを同一 & $\mathrm{CH}_{3} \mathrm{SiCl}_{3}$ & $\left(\mathrm{CH}_{3}\right)_{2} \mathrm{SiCl}_{2}$ & $\left(\mathrm{C}_{3} \mathrm{H}_{7}\right)_{3} \mathrm{SiH}$ \\
化合物より供 & $\mathrm{C}_{2} \mathrm{H}_{5} \mathrm{SiCl}_{3}$ & $\left(\mathrm{C}_{2} \mathrm{H}_{5}\right)_{2} \mathrm{SiCl}_{2}$ & $\left(\mathrm{CH}_{3}\right)_{4} \mathrm{Si}$ \\
給する原料ガ & $\mathrm{CH}_{3} \mathrm{SiH}_{3}$ & $\left(\mathrm{C}_{2} \mathrm{H}_{5}\right)_{2} \mathrm{SiH}_{2}$ & \\
ス系 & $\mathrm{CH}_{3} \mathrm{SiHCl}_{2}$ & $\left(\mathrm{CH}_{3}\right)_{3} \mathrm{SiCl}$ & \\
\hline SiよCを異な & $\mathrm{SiCl}_{4}+\mathrm{CH}_{4}$ & $\mathrm{SiF}_{4}+\mathrm{CH}_{4}$ & $\mathrm{SiHCl}_{3}+\mathrm{CCl}_{4}$ \\
る化合物より & $\mathrm{SiCl}_{4}+\mathrm{C}_{3} \mathrm{H}_{8}$ & $\mathrm{SiBr}_{4}+\mathrm{C}_{2} \mathrm{H}_{4}$ & $\mathrm{SiHCl}_{3}+\mathrm{C}_{5} \mathrm{H}_{12}$ \\
供給する原料 & $\mathrm{SiCl}_{4}+\mathrm{C}_{6} \mathrm{H}_{6}$ & $\mathrm{SiH}_{4}+\mathrm{CH}_{4}$ & $\mathrm{SiHCl}_{3}+\mathrm{CHCl}_{3}$ \\
ガス系 & $\mathrm{SiCl}_{4}+\mathrm{CCl}_{4}$ & $\mathrm{SiH}_{4}+\mathrm{C}_{3} \mathrm{H}_{8}$ & \\
\hline
\end{tabular}

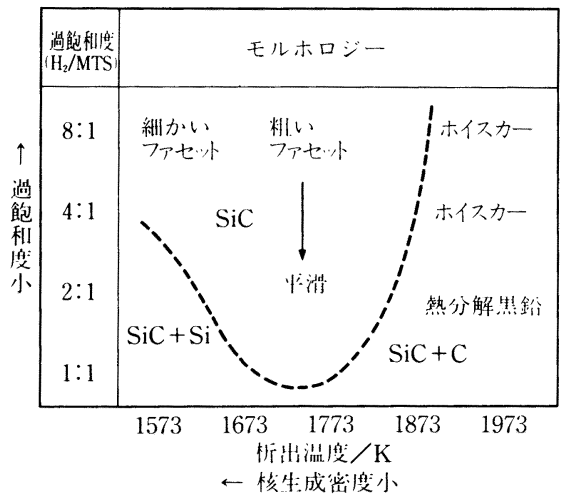

図 2 CVD-SiCのモルホロジー ${ }^{(23)}$.

の導入比率 (濃度)および析出温度による析出物の形態を 示す ${ }^{(23)}$. 図 2 に打いて, 点線の上側の領域で $\mathrm{SiC}$ 単相 が得られ，MTS 混合比が高く，かつ低温域では析出物 中に Si が含まれる。一方, 高温域では C が共析出する.

MTSからの $\mathrm{SiC}$ の生成にはキャリアーガスの種類も 影響する．1623〜 $1773 \mathrm{~K}$ ではキャリアーガスの影響は ほとんよ゙無いが，アルゴンは析出温度が 1373〜 1623 K の条件では Cの共析出を促進する ${ }^{(24)}$.

$\mathrm{SiCl}_{4}-\mathrm{C}_{3} \mathrm{H}_{8}$ 系 $\left(\mathrm{SiCl}_{4}\right.$ 流量 : $2.9 \times 10^{-6} \mathrm{~m}^{3} / \mathrm{s}, \mathrm{H}_{2}$ 流 量 : $\left.1.2 \times 10^{-5} \mathrm{~m}^{3} / \mathrm{s}\right)$ の合成結果の一例 $(100 \mathrm{kPa})$ を図 3 に示す ${ }^{(25)} \cdot \mathrm{C}_{3} \mathrm{H}_{8}$ 流量が約 $8.5 \times 10^{-7} \mathrm{~m}^{3} / \mathrm{s}$ 以上では $\mathrm{C}$ が共析出する。析出温度 : $1873 \mathrm{~K}$, ガス圧力 : $4 \mathrm{kPa}$,
$\mathrm{C}_{3} \mathrm{H}_{8}$ 流量 : $6.8 \times 10^{-7} \mathrm{~m}^{3} / \mathrm{s}, \mathrm{SiCl}_{4}$ 流量 : $2.9 \times 10^{-6} \mathrm{~m}^{3} / \mathrm{s}$, $\mathrm{H}_{2}$ 流量 : $1.2 \times 10^{-5} \mathrm{~m}^{3} / \mathrm{s}$ の条件で, $\mathrm{C}$ が共析出した ものの最高合成速度としては $0.5 \mu \mathrm{m} / \mathrm{s}(1.8 \mathrm{~mm} / \mathrm{h})$ が 得られている.

円筒状の黒鉛基材の内面への高強度 $(1.4 \mathrm{GPa}) \mathrm{SiC} コ ー$ ティングは, $2173 \mathrm{~K}, 0.7 \sim 1.3 \mathrm{kPa}$ の条件で，ガスの 線速度が $10 \sim 100 \mathrm{~m} / \mathrm{s}$ で行われている(23). しかし, 直 径 $\phi 127 \mathrm{~mm}$ のような大型基材へのコーティングの場 合には，ランニングコストの低减を計るために大気压近 傍のガス圧力が採用されることもある(20).

原料ガスと合成温度の関係を図 4 亿まとめて示す。

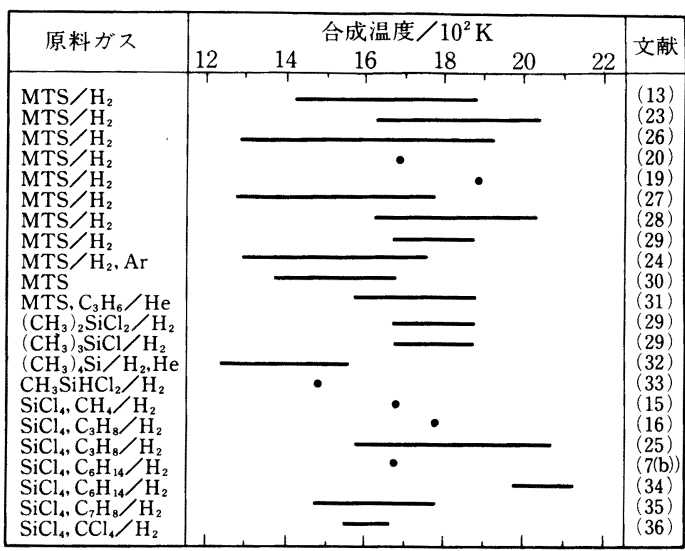

図 4 CVD-SiC の合成温度範囲.

\section{（3）合成装置}

\section{(i) 装置の構成}

CVD 装置の一般的な構成を図 5 亿示す.

(A) ガス導入系

原料ガスやキャリアーガスの流量や混合比が調整され る. MTS $\mathrm{CCl}_{4}$ のような液体原料の場合は, 温度制 御されたバブラーで蒸気圧を調整し, キャリアーガスで 搬送する.図 6 亿示したようなエバポレーターを使用し て，飽和度を制御した高い蒸気圧を得る場合もある(26).

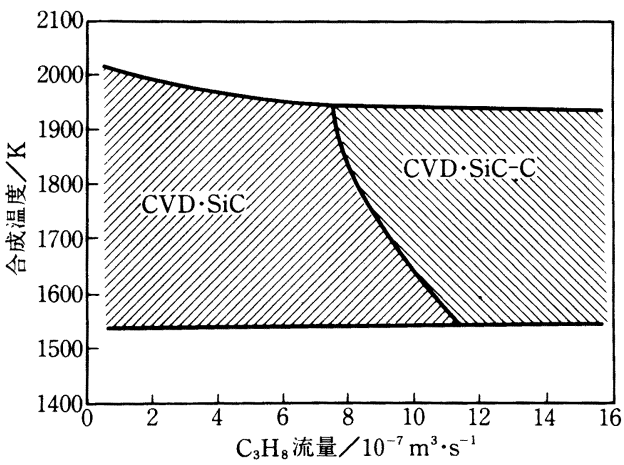

図 3 CVD-SiC の合成条件 ${ }^{(25)}$.

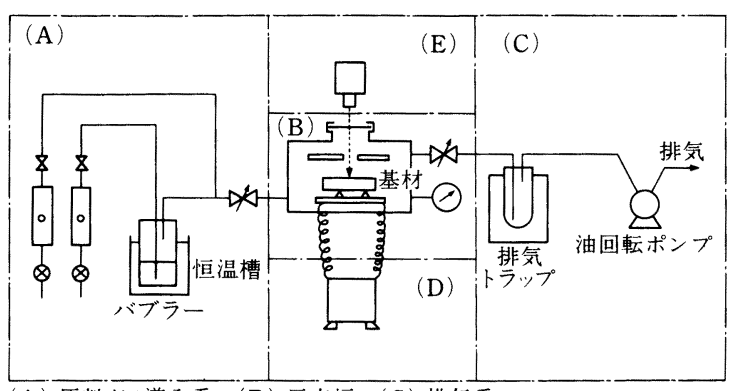

(A) 原料がス尊入系 (B) 反応炉 (C) 排気系

(D) 加熱電源 (E) 温度計測
図 5 CVD装置の構成. 


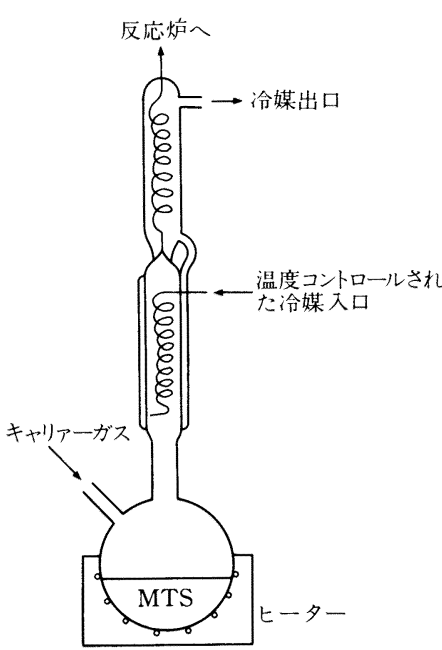

図6 MTS用エバポレーター ${ }^{(26)}$.

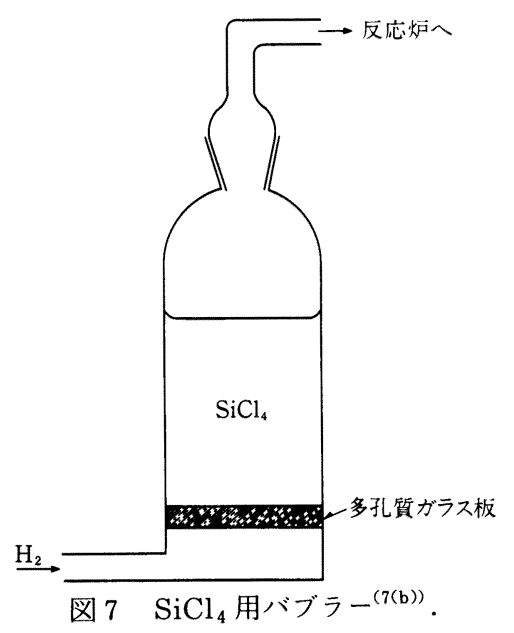

この場合には，エバポレーターと反応炉を結ぶ搬送管の 温度の制御が重要になる。図 7 に示したバブラーによれ ば，96〜98\%の飽和度が得られている(7(b)).

(B) 反応炉 (後述)

(C) 排気系

反応炉中の残留ガスの除去および反応炉の減圧操作の ために排気装置が必要である，腐食性のガスが大量に排 出されるので, 排気ポンプには耐食性ポンプが使われる. 通常の油真空ポンプを用いると, 油が侵されて絶えずポ ンプの清掃をするととになり, 非能率的である。最近で は, 油循環式真空ポンプや封液に水を用いた水封式真空 ポンプ, さらには油や水などの封液を一切必要としない ドライ真空ポンプが良く使われている. 気相反応により 生じた微粉末が同時に排出されるので, 排気装置の直前 に油トラップやフィルターが取り付けられることもある.

(D) 廃ガス処理系

反応によって生じたガスや末反応原料ガスおよびキャ リアーガスなよ゙が系外に排出されないようにするために 廃ガス処理装置が設置される. 特に最近では, CVD関 連の廃ガスが問題になり, 公害の面から廃ガスが規制さ れる方向にある. 反応副生成物の塩化水素などは, 活性 炭上に $\mathrm{NaOH}$ をコーティングした固体中和剤で吸収し たり，液体窒素トラップなどにより大部分除去すること ができる．さらに，スクラバーを通すことによりほぼ完 全に除去される. 多量の水素ガスの処理にはバーナーに よる燃焼措置がとられている。

(E) 加熱系

反応炉は，図 8 に示すように，基材を周囲から加熱す る Hot-wall 方式と, 基材を直接加熱し, 炉壁の温度 は上がらない Cold-wall 方式とに大別できる. 数種類 のお互いに反応し易い原料ガスを導入するような場合之 か小規模実験装置としては Cold-wall 方式が良いが, $\mathrm{SiC}$ の場合は, 前述したように, 用いられる原料ガス相 互の間に反応が生じないので, Hot-wall 方式が有利で ある. Hot-wall 方式は複雑形状の基材上へのコーティ ングに適し, 量産性に優れている.しかし, 外壁への析 出物の付着が欠点である. 加熱方法には, 黒鉛などのヒー ターに大電流を流して加熱する方法と高周波により加熱 する方法がある. 最近では，レーザー加熱む採用されて いる.

(F) 測温系

基材の測温には, 熱電対, 光高温計, 放射温度計など が用いられる，腐食性雾用気中で熱電対を用いる場合に は BN 製保護管などで被覆する必要がある。光高温計 を用いた場合は，ガスによるくもりの影響や測温空の污 れに注意する必要がある。乙のため，黒鉛を基材にする ときには，十分に空焼きして脱ガスしなくてはならない.

(a) Cold-wall 方式
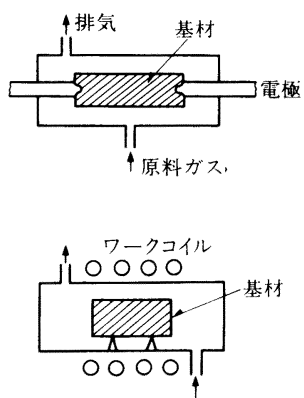

(b) Hot-wall 方式
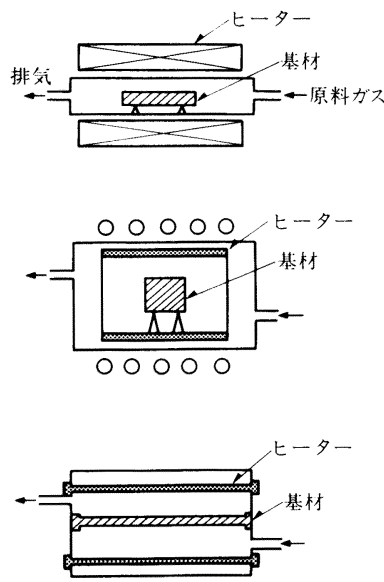

図 8 反応炉の分類と模式図. 
(ii) 反応炉

(A) 横型炉

著者等 ${ }^{(25)}$ は, 二重管ガスノズルを有する Cold-wall 式反応炉を用いている(図 9). チャンバー径は $0.28 \mathrm{~m}$ で, $40 \times 12 \times 2(\mathrm{~mm})$ の黒鉛基材を直接加熱する方法を とっている. 原料は $\mathrm{SiCl}_{4}$ と $\mathrm{C}_{3} \mathrm{H}_{8}$ で, $1573 \sim 2073 \mathrm{~K}, 4$ $\sim 100 \mathrm{kPa}$ の条件で, 最高 $0.39 \mu \mathrm{m} / \mathrm{s}(1.4 \mathrm{~mm} / \mathrm{h})$ の合 成速度で $\mathrm{SiC}$ が得られている。

Kobayashi 等 ${ }^{(24)}$ は, 図 10 亿示すように, 管状電気 炉に $\phi 20 \mathrm{~mm}$ のアルミナ管を通した炉を用いた。基材 は黒鉛である．原料は MTS で, 合成温度は 1273 1773 Kである。乙のタイプの炉では, 原料ガスが基材に到 達するまでに加熱され, 気相反応が生じるので, 加熱部 の温度勾配が重要になる。

同じ横置き型で, Chown 等 ${ }^{(7(b))}$ は, 反応炉内に設け た長さ $127 \mathrm{~mm}$ の黒鉛サセプターを誘導加熱 $(22 \mathrm{~kW}-500$ $\mathrm{kHz}$ )する方法を採用した. 図 11 に示すように, 石英管 をチャンバーとして用い, 両端をシャープエッジとして 水冷アダプターにはめ込まれた鉛ガスケットにこのエッ ジを押し付けて気密を保たせた。彼等は，乙の炉を用い て, 原料に $\mathrm{SiCl}_{4}$ とへキサンを使い, 合成温度 $1673 \mathrm{~K}$ で黒鉛製のロケットノズル $(\phi 76 \mathrm{~mm} \times L 76 \mathrm{~mm})$ に $0.1 \mu \mathrm{m} / \mathrm{s}$ の速度で $\mathrm{SiC} コ$ ティングを行った. 石英管 とサセプターの隙間で析出が生じないように対策が講じ られているようである。

Balog 等 ${ }^{(37)}$ は, Si ウェハー上へのコーティングに, 同様な横置き型の装置を使用した。図 12 に示すように,
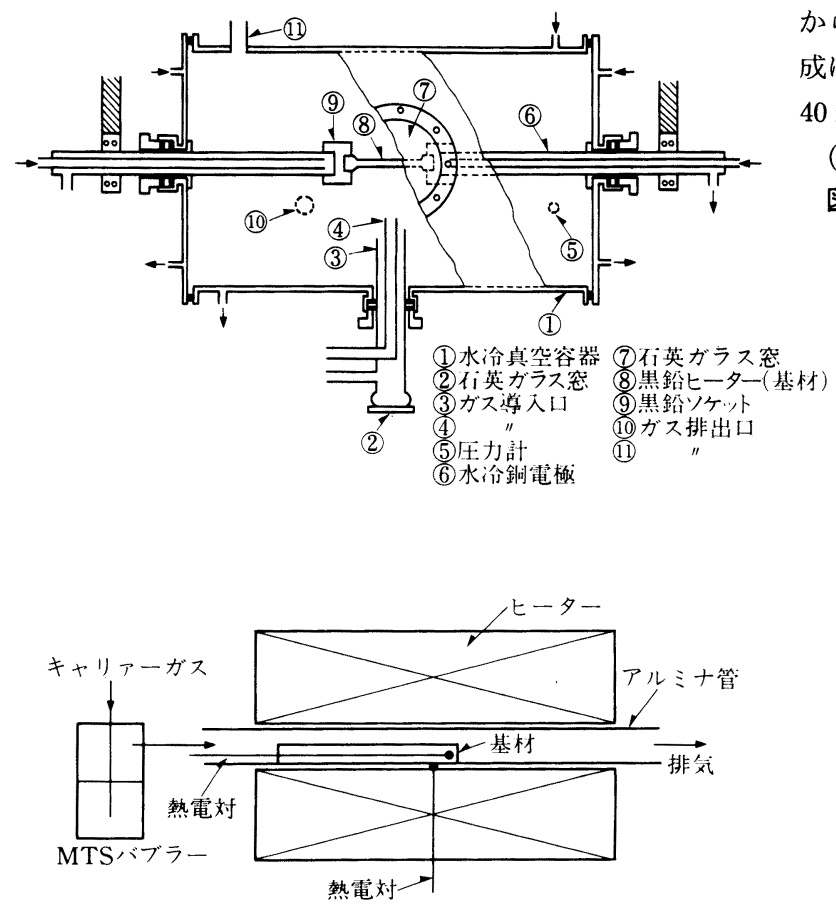

図 10 典型的な Hot-wall 式反応炉 ${ }^{(24)}$.

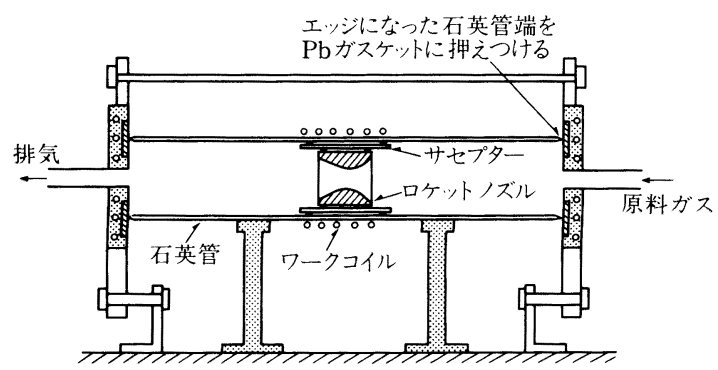

図 $11 \mathrm{~Pb}$ ガスケットにより気密性を達成した反応 炉(7(b)).

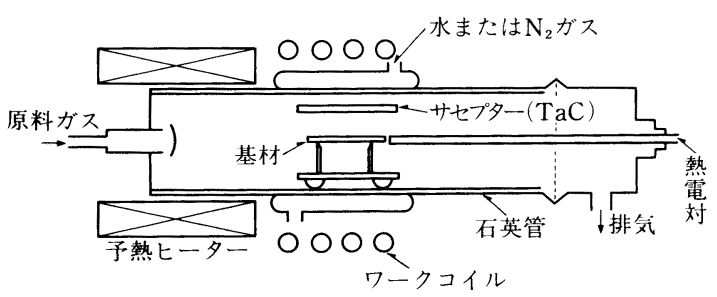

図 12 原料ガス予熱ヒーターを有する反応炉 ${ }^{(37)}$.

チャンバーは石英管で，中央付近に水冷ジャケットが付け られている.サセプターは $\mathrm{TaC}$ をーティングした $\mathrm{Ta}$ で, $40 \mathrm{~mm} \times 25 \mathrm{~mm}$ の矩形断面をした長さ $150 \mathrm{~mm}$ の チューブである. 台座にはサファイアが用いられている. 誘導加熱電源は $20 \mathrm{~kW}-300 \mathrm{kHz}$ である. 合成温度は 1473 $1623 \mathrm{~K}$, 原料ガスは $\mathrm{CH}_{4}$ で, 反応炉の原料ガス 入口寄りで予備加熱されている. 基材が $\mathrm{Si}$ であること から，不純物の混入を避けるために上述したような炉構 成になっている. Si 基材と析出した $\mathrm{C}$ との反応により, $40 \mathrm{~nm}$ 厚さの $\mathrm{SiC}$ 膜が得られている.

(B) 縦型炉

図 13 は Cartwright 等 ${ }^{(26)}$ が使用した縦型管状炉であ

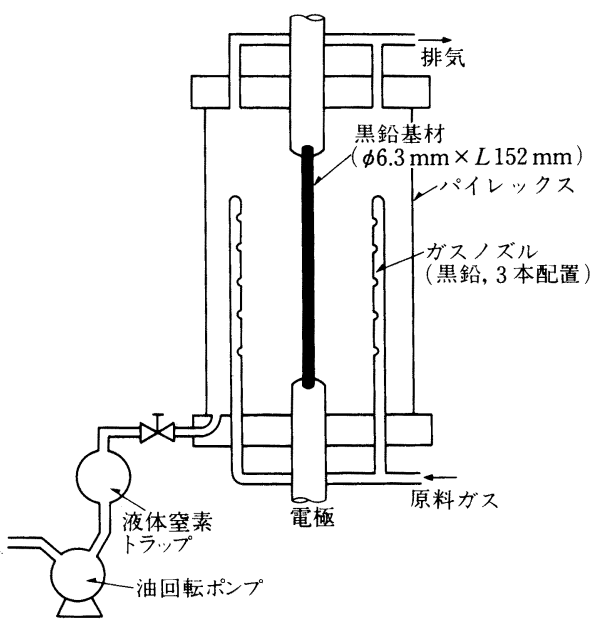

図 13 多孔ノズルを設けた反応炉 ${ }^{(26)}$. 
る. 基材には $\phi 6.3 \mathrm{~mm} \times L 152 \mathrm{~mm}$ の黒鉛棒が用いら れ, 基材は直接通電により加熱されている.チャンバー はパイレックス製で，上下のアダプターおよび電極は水 冷されている．原料ガス (MTS)の導入には基材と同じ 長さの，小さな孔 $(\phi: 0.8 \mathrm{~mm})$ をたくさん開けた黒鉛 製のノズル $(\phi: 6.3 \mathrm{~mm})$ が用いられている.ノズルの 採用に加えて，排気口を 3 力所設けるととにより，反応 ガスの分布の均一化が計られている.

また，Cartwright 等 ${ }^{(26)}$ は図 14 亿示すような炉で, ロケットノズルへのコーティングを行った，反応炉は， パイレックス製のチャンバー内にワークコイルを入れて, 基材の黒鉛ロケットノズルを直接誘導加熱し，内面をコー

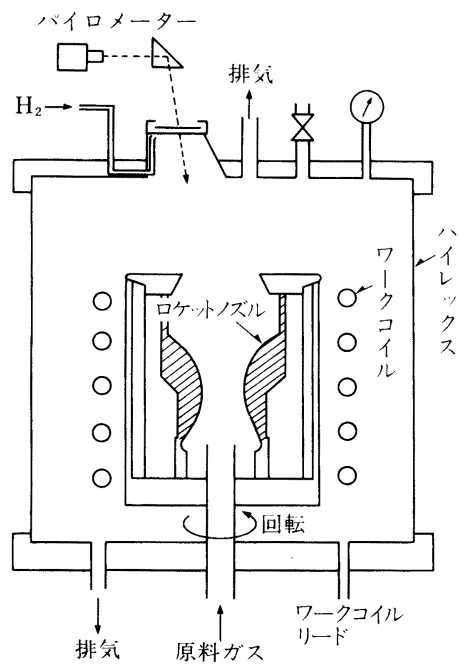

図 14 回転機構をむつロケットノズルコーティング 用反応炉 ${ }^{(26)}$.

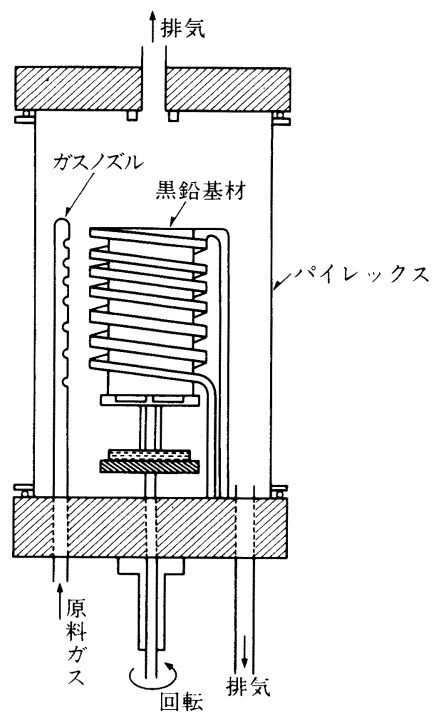

図 15 回転機構とガスノズルを併用した反応炉 ${ }^{(20)}$.
ティングする，基材は断熱のために黒鉛フェルトが巻か れている．基材は黒鉛テーブルに載せられ，均一なコ一

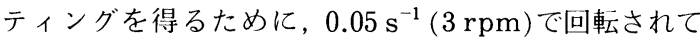
いる．原料ガス (MTS) は中空のテーブル回転軸の中を 通じて下部より導入され，一度障害板に当てられて均一 な分散が計られている。

Lloyd 等 ${ }^{(20)}$ は MTSを原料とし，図 15 亿示すような 誘導加熱によって, $1673 \mathrm{~K}$ で, $\phi 127 \mathrm{~mm} \times L 152 \mathrm{~mm}$, 肉厚 $1.5 \mathrm{~mm}$ の $\mathrm{SiC}$ チューブの作製を試みた。すな水 ち, 基材の黒鉛チューブの内側に $\mathrm{SiC}$ を析出させた後 に基材を除去して得ら扎る，基材は回転テーブル上にセッ

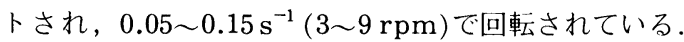
均一な厚さの析出物を得るために，原料ガスは小孔を開 けた一端封じのアルミナ管 $(\phi 8 \mathrm{~mm})$ からワークコイル の間隙を経て基材に吹き付けられている.

Weiss 等 ${ }^{(28)}$ は図 16 亿示すような抵抗加熱炉 (合成温 度：1623〜2023 K)を用い，MTSを原料として，黒鉆

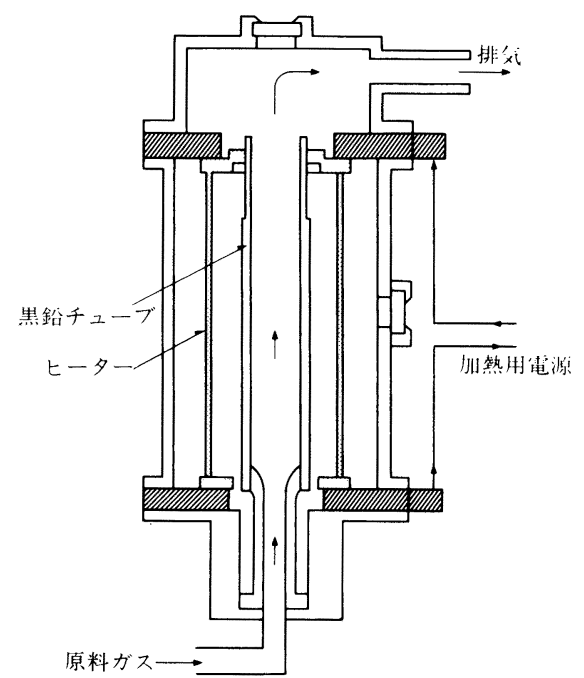

図 16 チューブ内面へのコーティング用 Hot-wall 式反応炬 ${ }^{(28)}$

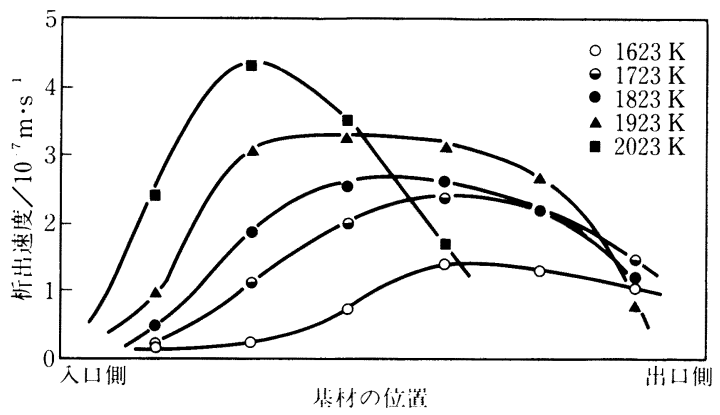

図 17 図 16 の反応炬における基材の位置と析出速 度の関係 ${ }^{(28)}$. 
チューブの内側に $\mathrm{SiC}$ を析出させた. このタイプの炉 では温度勾配が生じ，場所によって析出速度が異なる。 その研究例を図 17 に示す.

Emyashev 等(15) は, $\mathrm{SiCl}_{4}$ よ $\mathrm{CH}_{4}$ を原料ガスとして, 図 18 亿示すような炉を用いて, $1673 \mathrm{~K}$ で直接通電によ り加熱された黒鉛チューブの内側に CVD-SiCを合成 している.乙の時の合成速度は比較的早く, $0.05 \mu \mathrm{m} / \mathrm{s}$ である。

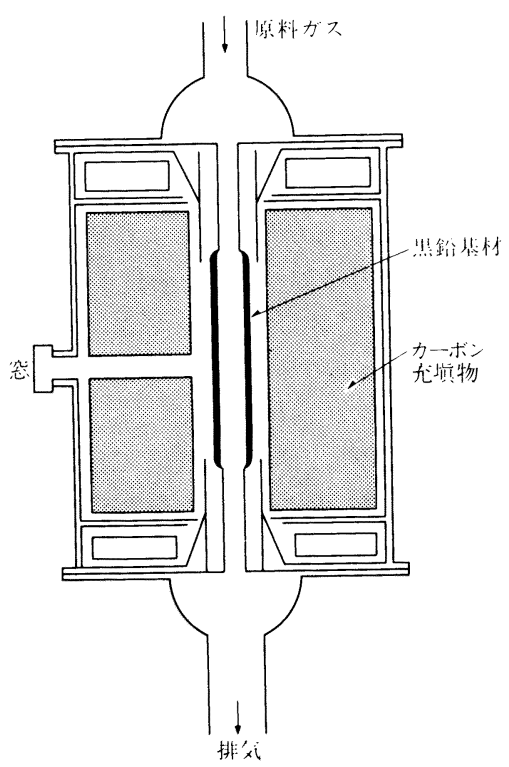

困 18 チューブ内面へのコーティング用 Cold-wall 式反応炉 ${ }^{(15)}$.

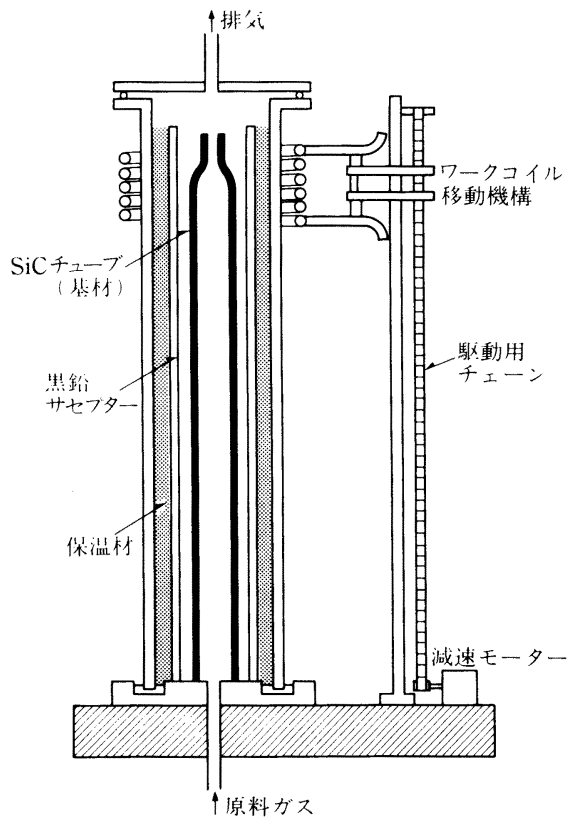

図 19 可動式のワークコイルをむつ反応炉 ${ }^{(38)}$.
長尺のチューブの内側に CVDコーティングを行う装 㯰として図 19 に示すような炉がある.乙れは金属を精 製するときに用いられるゾーンメルティングと同じよう な装置で, ワークコイルが一端から他端まで移動するこ とによって，全体にわたって均一なコーティングが得ら れるそうである(38). 析出温度が異なっても, 全く同じ 析出物が得られるあのであれば，乙の装置は有用かむし れない.

(C) ベルジャ一型炉

図 20 にその一例を示す. 石英製ベルジャ一内に黒鋁 柱をサセプターとして設置し，その上に Si 抢よび C 基 板を置いたものである ${ }^{(27)} . \mathrm{SiCl}_{4}$ を原料として, 1373 〜 $1773 \mathrm{~K}$ で, Si および SiC が得られている.

(D) 固体原料を使用した炉

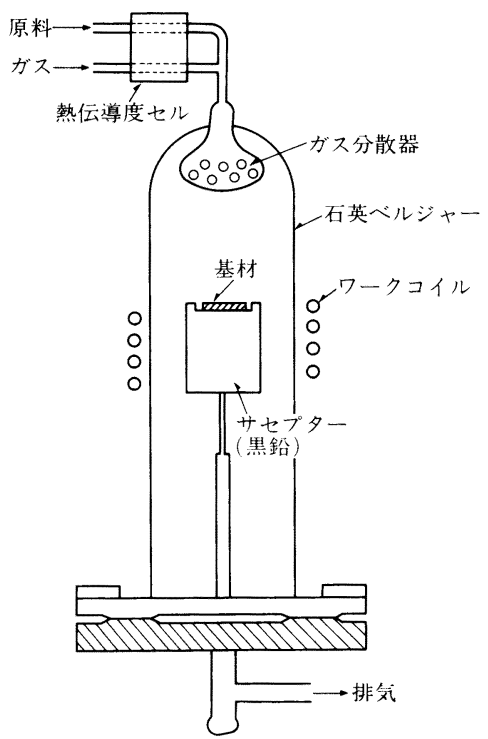

図 20 ガス分散器を有する反応炉 ${ }^{(27)}$

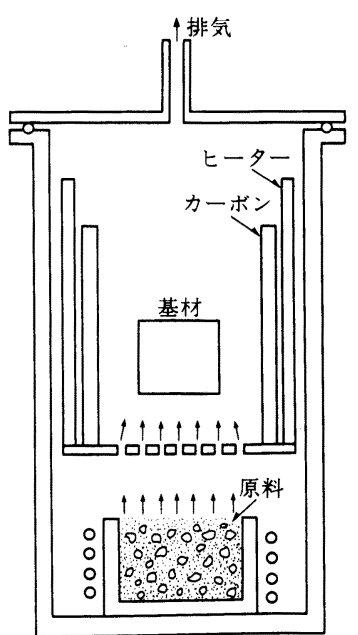

図 21 固体原料用反応炉 ${ }^{(39)}$ 
てれは上述した炉とはかなり異なったものである．図 21 に示すように, シリカ粉末之炭素粉末を加熱して SiO と $\mathrm{CO}$ ガスを発生させ，乙れを上部に導き，基材上に $\mathrm{SiC}$ を得るむのである。乙の方法では，合成速度は低い が，結晶性の良いむのが得られるはずである．

\section{4. $\mathrm{SiC}$ 基 in-situ 複合セラミックスの CVD}

最近，CVD-SiCをマトリックスとする複合材料 に関心が寄せられている。乙れは，CVD法で $\mathrm{SiC}$ を 合成する際に他のガスを添加導入するてとによって, 材料を合成するプロセスで同時に複合化を行う方法であ る. 乙の方法で合成される複合材料は「CVD in-situ Composite」といわれ，また，分散相の大きさが数 $\mathrm{nm}$ と非常に小さいことから「ナノ・コンポジット」とも呼 ばれ，新しい性質の発現が期待されている(40).

$\mathrm{SiC}$ 基では, $\mathrm{Si}-\mathrm{C}-\mathrm{Ti}^{(41)}, \mathrm{Si}-\mathrm{C}-\mathrm{B}^{(42)}$ 系の in-situ複

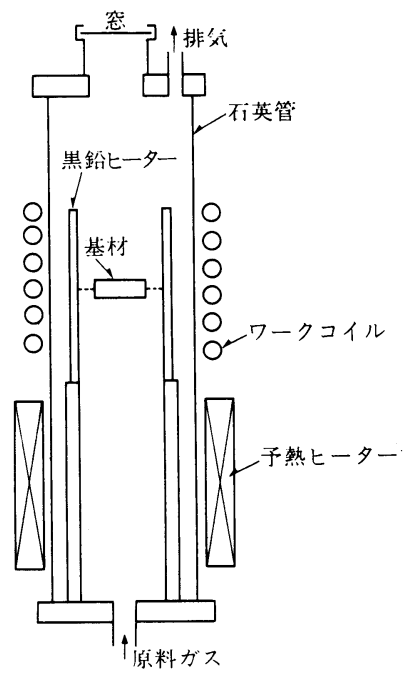

図 22 予熱ヒーターを有する $\mathrm{Si}-\mathrm{C}$ - B 系in-situ 複合セラミックス合成用反応炉 ${ }^{(42)}$.

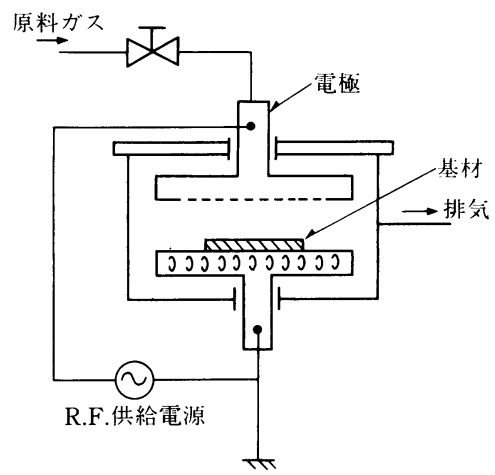

図 $23 \mathrm{Si}-\mathrm{C}-\mathrm{N}$ 系薄膜材料の合成に用いられたプ ラズマ CVD 用反応炉 ${ }^{(43)}$.

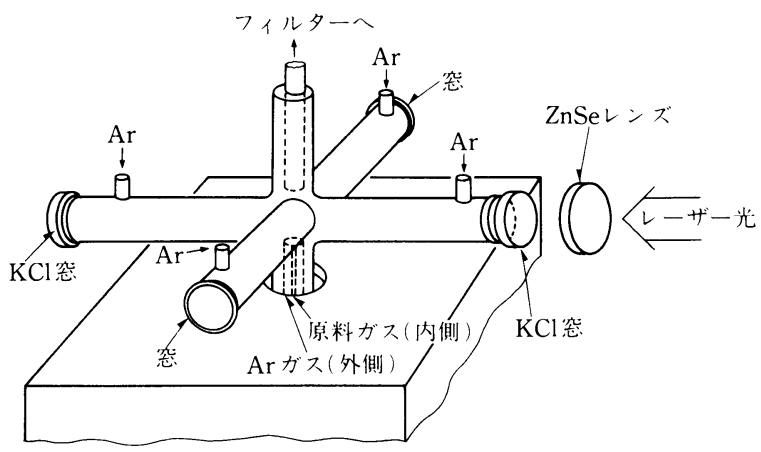

図 24 S.i-C-N 系粉末の合成に用いられたレーザー CVD 用反応炉 ${ }^{(44)}$.

合セラミックスの合成が筆者らにより試みられている.

図 22 に示すような予熱ヒーターを有する Hot-wall 式 縦型反応炉を用い, $\mathrm{SiCl}_{4}, \mathrm{BCl}_{3}$ および $\mathrm{C}_{3} \mathrm{H}_{8}$ ガスを原 料として， $\mathrm{SiC}$ マトリックスに B を 1 質量\% 程度含む 複合セラミックスが合成されている(42). また, 図 23 や図 24 に示すように, $\mathrm{SiH}_{4}, \mathrm{NH}_{3}, \mathrm{CH}_{4}$ (または $\mathrm{C}_{2} \mathrm{H}_{4}$ ) 执よび $\mathrm{H}_{2}$ を原料ガスとしたプラズマ $\mathrm{CVD}^{(43) や, ~}$ $\left(\left(\mathrm{CH}_{3}\right)_{3} \mathrm{Si}\right)_{2} \mathrm{NH}$ を原料ガスとしたレーザー $\mathrm{CVD}^{(44)}$ 用いた, $\mathrm{Si}-\mathrm{C}-\mathrm{N}$ 系の複合セラミックスも合成されて いる.

\section{5. おわりに}

本稿で紹介された CVD-SiC 合成炉は，報告された 屯のの一部にしかすぎない，CVDは原料ガスの流れに 著しく影響される. 従って, 炉の形状および炉内部の構 造は良質の CVD-SiC を得る上で重要であるが，その 詳細は当然のてととはいえ報告されていない，近年, 反 応炉内でのガスの流れがコンピューターシミュレーション によって解析されるようになった。 さらに，ガスの流れ の基礎的研究のために宇宙実験室を用いることを著者ら は検討している. これらの基礎研究の積み重ねにより, 近い将来, CVDはknow-how から一般的な技術にな るものと思われる。

\section{文献}

（1）平井敏雄：日本金属学会会報, 17(1978), 313 .

（2）笛木和雄：セラミックス, 13(1978), 3.

(3) 榎本 亮: セラミックス, 17(1982), 828.

（4）鈴木弘茂: セラミックス, 18(1983)，3.

（5）岡村清人, 平井敏雄: 金属物理セミナー, 3(1978), 75.

(6) (a)菊池則文, 西山昭雄 : セラミックス, 17(1982), 623. (b) 井川勝市: セラミックス, 17(1982), 621.

( 7 ) (a)W.V.Kotlensky and D.H.Leeds : Proc. the 3rd Int. Conf. on Chemical Vapor Deposition, Ed. by F.A. Glaski, The Electrochem. Soc., New Jersey, (1972), p.574.

(b) J.Chown, R.F.Deacon, N.Singer and A.E.S.White : Special Ceramics 5, Ed. by P. Popper, The British Ceramic Research Association, London, (1962), p.81. 
( 8 ) L. J. Korb, C. A. Morant, R. M. Calland and C. S. Thatcher: Amer. Ceram. Soc. Bull., 60(1981), 1188.

( 9 ) G.E.Blair, J.H.Shafer, J.J.Meyers and F.T.J.Smith: US Pat. 4139677, (1979).

(10) (a) R.E.Engdahl : Soc. Automotive Engineers, 740184, (1974).

(b) M.L.Torti : ibid., 740242, (1974).

(11) P.Z.Takacs : Nucl. Instrum. Methods, 195(1982), 259.

（12）松波弘之：伈用物理，48(1979), 565.

(13) J.Chin, P.K.Gantzel and R.G.Hudson: Thin Solid Films, 40(1977), 57.

(14) K.Hiraga, M.Hirabayashi, K.Niihara and T.Hirai Proc. the 9th Int. Conf. on Chemical Vapor Deposition, Ed. by McD.Robinson, et al., The Electrochem. Soc., New Jersey, (1984), p.575.

(15) A.V.Emyashev, A.I.Lutkov, L.N.Panshin and A.S. Tarabanov: Izvest. Akademi. Nauk USSR, Neorg. Mat., 9(1973), 1924.

(16) K.Niihara, A.Suda and T.Hirai : Proc. Int. Symp. on Ceram. Components for Engine, Ed. by S.Somiya, E. Kanai and K.Ando, KTK Scientific Publishers, Tokyo, (1983), p.480.

(17) J.W.Edington, D.J.Rowcliffe and J.L.Henshall : Powder Met. Int., 7(1975), 82.

(18) 平井敏雄, 新煌䧊一, 林 真輔：セラミックス, 13(1978), 861.

(19) P.Popper and I.Mohyuddin : Special Ceramics 1964, Ed. by P.Popper, The British Ceramic Research Association, London, (1965), p.45.

(20) D.E.Lloyd and V.C.Howard : Special Ceramics 1966, Ed. by P.Popper, The British Ceramic Research Association, London, (1967), p.103.

(21) 佐々木 真, 大久保 昭, 平井敏雄: 第 5 回春季(東京) 粉体粉木治金協会講演概要集，(1985), p.154.

(22) J.Schlichting : Powder Met. Int., 12(1980), 141

(23) J.R.Weiss and R.J.Diefendorf : Proc.the 4th Int. Conf. on Chemical Vapor Deposition, Ed. by G.F.Wakefield and J.M.Blocher, Jr., The Electrochem. Soc., New Jersey, (1973), p.488.

(24) F.Kobayashi, K.Ikawa and K.Iwamoto: J. Crystal Growth, 28(1975), 395.

（25）平井敏雄, 後藤 孝, 怩 利彦: 窝業協会誌, 91(1983), 502 .
(26) B.S.Cartwright and P.Popper : Science of Ceramics 5, Ed. by P.Popper, The British Ceramic Soc., London, (1969), p.473.

(27) I.L.Kalnin and J.Rosenstock : Electrochemical Technology, 4(1966), 492.

(28) J.R.Weiss and R.J.Diefendorf : Silicon Carbide-1973, Ed. by R.C.Marshall, J.W.Faust, Jr. and C.E.Ryan, University of South Carolina Press, Columbia, (1974), p. 80.

(29) W.V.Muench and E.Pettenpaul : J. Electrochem. Soc., 125(1978), 294.

(30) L.Aggour, E.Fitzer, E.Ignotowitz and M.Sahebkar : Carbon, 12(1974), 358.

(31) J.L.Kaae and G.H.Reynolds : J. Nucl. Mater., 58(1975), 237.

(32) Y.Avigal and M.Schieber: J. Crystal Growth, 24/25 (1974), 188.

(33) F.Galasso, M.Basche and D.Kuehl: Appl. Phys. Lett., 9(1966), 37.

(34) W.V.Muench and I.Pfaffeneder : Thin Solid Films, 31 (1976), 39.

（35）河嶋千寿，瀬高信雄，中川順吉：黨業協会誌，75(1967), 48.

(36) N.Setaka and K.Ajiri : J. Amer. Ceram. Soc., 55(1972), 540.

(37) M.Balog. A.Reisman and M.Berkenblit: J. Electronic Mater., 9(1980), 669.

（38）松尾秀逸, 宇山長輝, 田口啓輔, 橴谷隆之: 特開昭 5490215, (1979)

（39）松尾秀逸，保科勝見：特開昭 54-90216, (1979).

(40) T.Hirai and T.Goto: Tailoring Multiphase and Composite Ceramics, Ed. by R.E.Tressler, G.L.Messing, C. G.Pantano and R.E.Newnham, Plenum Press, New York, (1986), p.165.

（41）後藤 孝, 平井敏雄: 日本金属学会講演概要, (1986.10 月), p. 192 .

(42) 佐々木 真, 楠美康夫, 平井敏雄: 特開昭 61-43788, (1986).

(43) K.Kamata, Y.Maeda and M.Moriyama : J. Mat. Sci. Lett., 5(1986), 1051.

(44) G.W.Rice : J. Amer. Ceram. Soc., 69(1986), C-183. 